\title{
PELVIC INCIDENCE AND OSTEITIS PUBIS IN PROFESSIONAL SOCCER PLAYERS
}

\section{INCIDÊNCIA PÉLVICA E OSTEÍTE PÚBICA EM JOGADORES PROFISSIONAIS DE FUTEBOL}

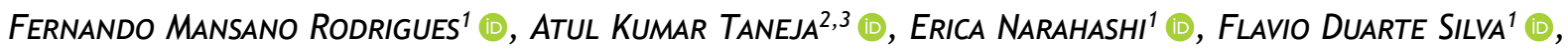

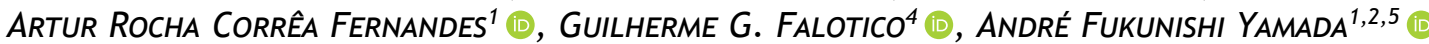 \\ 1. Universidade Federal de São Paulo, Escola Paulista de Medicina (UNIFESP- EPM), Diagnostic Imaging Department (DDI), São Paulo, Brazil. \\ 2. Hospital do Coração (HCor), Diagnostic Center, Musculoskeletal Imaging, São Paulo, Brazil. \\ 3. Hospital Israelita Albert Einstein, Imaging Department, Musculoskeletal Division, São Paulo, Brazil. \\ 4. Universidade Federal de of São Paulo, Escola Paulista de Medicina (UNIFESP. EPM), Traumatology and Orthopedics Department, São Paulo, Brazil \\ 5. Diagnósticos da América SA (DASA), ALTA Diagnósticos, São Paulo, SP, Brazil.
}

\section{ABSTRACT}

Introduction. Osteitis pubis is a common inflammatory disease of the pubic symphysis, defined as a chronic pain syndrome caused by repetitive microtrauma. Since adaptative changes are necessary in the pelvis to adjust the equilibrium of the myotendinous structures, the aim of this study was to evaluate the correlation between pelvic incidence and osteitis pubis among professional soccer players. Materials and Methods. An observational, crosssectional study was performed with professional soccer players from five teams during pre-season. Athletes with previous congenital pelvic abnormalities or a history of surgery were excluded. Radiographs of the pelvis were analyzed by two radiologists and assessed for findings consistent with osteitis pubis, and the following parameters were measured: pelvic incidence $(\mathrm{PI})$, sacral inclination (SI), and pelvic version (PV). Results. A total of 107 subjects were included in the study, with a mean age of $25.6 \pm$ 3.1 years. Findings compatible with osteitis pubis were present in $74.8 \%$ of the subjects $(80 / 107)$. There was no statistical correlation between osteitis pubis and $\mathrm{PI}\left(52.3^{\circ} \pm 12.7^{\circ}\right.$ vs. $48.4^{\circ} \pm 10.8^{\circ}$; $p=0.156)$, SI $\left(43.1^{\circ} \pm 9.8^{\circ}\right.$ vs. $\left.39.9^{\circ} \pm 10.1^{\circ} ; p=0.146\right)$, or PV $\left(9.2^{\circ} \pm\right.$ $6.3^{\circ}$ vs $\left.8.6^{\circ} \pm 7.5^{\circ} ; p=0.649\right)$. Agreement between readers was excellent $(p<0.0001)$. Conclusion. There was no significant correlation between pelvic parameters and radiographic diagnosis of osteitis pubis. Leve of Evidence II; Diagnostic study.

Keywords: Sports medicine. Pubic symphysis. Pelvis. Soccer.

\section{RESUMO}

Introdução. A osteíte púbica é uma doença inflamatória comum da sínfise púbica, definida como síndrome de dor crônica causada por microtraumas de repetição. Uma vez que são necessárias mudanças adaptativas na pelve para adequar o equilíbrio das estruturas miotendíneas, o objetivo deste estudo foi avaliar a correlação entre e a incidência pélvica e a osteíte púbica em jogadores profissionais de futebol. Materiais e Métodos. Estudo transversal, observacional, conduzido com jogadores profissionais de futebol de cinco times profissionais durante a pré-temporada. Foram excluídos do estudo atletas com anormalidades congênitas prévias ou com história de cirurgia. As radiografias de pelve foram avaliadas por dois médicos radiologistas quanto aos achados compatíveis com osteíte púbica, e os seguintes parâmetros foram medidos: incidência pélvica (Pl), inclinação sacral (SI) e versão pélvica (PV). Resultados. Foram incluídos 107 participantes, com média de idade de 25,6 \pm 3,1 anos. Achados compativeis com osteíte púbica estavam presentes em $74,8 \%$ dos indivíduos (80/107). Não houve correlação estatística entre osteíte púbica e PI (52, $3^{\circ} \pm 12,7^{\circ}$ vs. $\left.48,4^{\circ} \pm 10,8^{\circ} ; p=0,156\right)$, SI $\left(43,1^{\circ} \pm 9,8^{\circ}\right.$ vs. $\left.39,9^{\circ} \pm 10,1^{\circ} ; p=0,146\right)$ ou PV $\left(9,2^{\circ} \pm 6,3^{\circ}\right.$ vs. $8,6^{\circ}$ $\left.\pm 7,5^{\circ} ; p=0,649\right)$. A concordância entre os médicos radiologistas foi excelente $(p<0,0001)$. Conclusões. Não houve correlação significativa entre os parâmetros pélvicos e o diagnóstico radiográfico de osteíte púbica. Nível de Evidência II; Estudo diagnóstico.

Descritores: Medicina esportiva. Sínfise pubiana. Pelve. Futebol.

Citation: Rodrigues FM, Taneja AK, Narahashi E, Silva FD, Fernandes ARC, Falotico GG, Yamada AF. Pelvic incidence and osteitis pubis in professional soccer players. Acta Ortop Bras. [online]. 2022;30(1): Page 1 of 5. Available from URL: http://www.scielo.br/aob.

\section{INTRODUCTION}

In the current sportive scenario, pubic symphysis is a joint that has gained lot of attention in recent years. Part of the pelvic girdle, pubic symphysis became target of a considerable frequent but difficult to diagnose entity: osteitis pubis. ${ }^{1}$
Currently, osteitis pubis is considered the most common inflammatory disease of the pubic symphysis and it is defined as a chronic pain syndrome caused by repetitive microtrauma. ${ }^{2,3}$ Osteitis pubis is especially prevalent in sports with "kicking" movement, as soccer, and is frequently associated with aponeurotic, tendinous or muscular

All authors declare no potential conflict of interest related to this article.

The study was conducted at Universidade Federal de São Paulo (UNIFESP), Escola Paulista de Medicina, São Paulo, SP, Brazil.

Correspondence: Atul K.Taneja. Hospital do Coração (HCor). Rua Des. Eliseu Guilherme, 69, 70 Andar. São Paulo, SP, Brazil. 04004-030. tanejamsk@gmail.com 
malfunction ${ }^{3}$. Both adductors and rectus abdominis muscles are inserted at the symphysis pubis, but they act antagonistically, creating increased mechanical traction and repetitive microtraumas that can predispose to a symphyseal imbalance and ultimately to osteitis pubis. ${ }^{4-6}$

Osteitis pubis represents a complex entity and the wide spectrum of changes seen in osteitis pubis are related with one of the most important principles of physiology of exercise: the adaptability, and also with the balance between the pelvis and the gravity center. There is no consensus about normal sagittal balance values, since there is a great variability between individuals. ${ }^{6-8}$ Even though, one can define a normal spinopelvic sagittal balance as that most frequently observed in asymptomatic subjects, meaning a harmonic balance of the axial body segment to the bicoxofemoral axis (defined by a line crossing the head of both femoral heads) with minimum muscular energy expenditure. Such balance has the aim to position the gravity line of upper body segment (head, trunk and upper extremities) during orthostasis, in low torque situation than bicoxofemoral axis itself and the global gravity line in a strict zone of support. This posture means that osteoarticular and myofascial elements will work in synchrony avoiding early degenerative and malfunction changes. ${ }^{8}$

Many authors that established radiological parameters to assess sagittal balance reinforced the importance of the pelvic position in vertebral statics. ${ }^{1,3,8-11}$ The literature has defined the mean pelvic incidence angle as $50^{\circ}$ in the adult asymptomatic population. ${ }^{12}$

The objective of this study is to evaluate the correlation between pelvic incidence and osteitis pubis among professional soccer players. Since adaptative changes are necessary to the pelvis in order to adequate myotendinous structures equilibrium, we sought to investigate if alterations to athletes' sagittal balance and pelvic parameters are related to osteitis pubis.

\section{MATERIALS AND METHODS}

An observational and cross-sectional study was conducted after approval by the Research Ethics Committee (CEP) from our institution. Subjects were recruited from five professional soccer teams during pre-season evaluation, from Jan 2016 to April 2016, by the Sports Medicine Section from Orthopedics and Traumatology Department of our institution.

Inclusion criteria consisted in male athletes and active soccer players. Exclusion criteria were history of congenital pelvic abnormalities, previous pelvic surgeries, or absence of pelvic and spine radiographs from childhood.

\section{Imaging studies}

All parameters were evaluated using Surgimap ${ }^{\circledR}$ software by two independent readers: a third-year radiology resident and a boardcertified orthopedic surgeon. Findings consistent with osteitis pubis were assessed using pelvic radiographs in anteroposterior view. Osteitis pubis was considered in the presence of sclerosis and/ or lytic abnormalities, and osseous protuberances. The following pelvic parameters were measured using lateral views:

- Pelvic incidence (PI) was defined as the angle formed by the crossing of a perpendicular line drawn from the middle point of the superior sacral plateau towards the sacral end and a line that unites both femoral heads centers, also known as bicoxofemoral axis (Figure 1).

- Pelvic version (PV) was defined as the angle formed at the femoral head by crossing a vertical line and a line that unites the middle point of the superior sacral plateau to the femoral head center (Figure 2). - Sacral inclination (SI) was defined as the angle formed by crossing a horizontal line and a line passing through the superior sacral plateau (Figure 3).

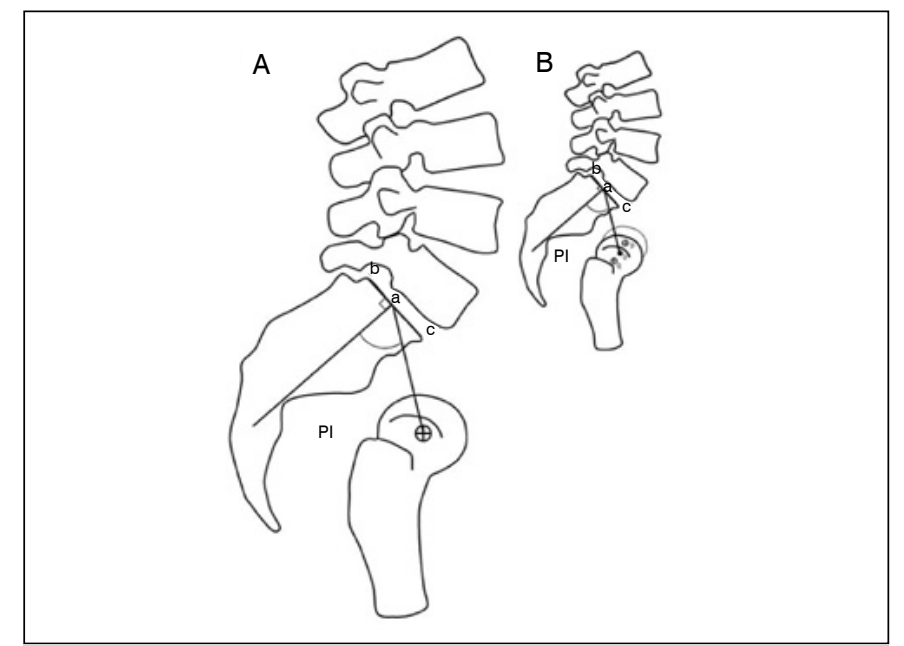

Figure 1. Pelvic incidence $(\mathrm{PI})$ is the angle formed between a line crossing the femoral head to middle point of sacral plateau (o-a) and a perpendicular line from sacral plateau (b-c) to sacral end (a).

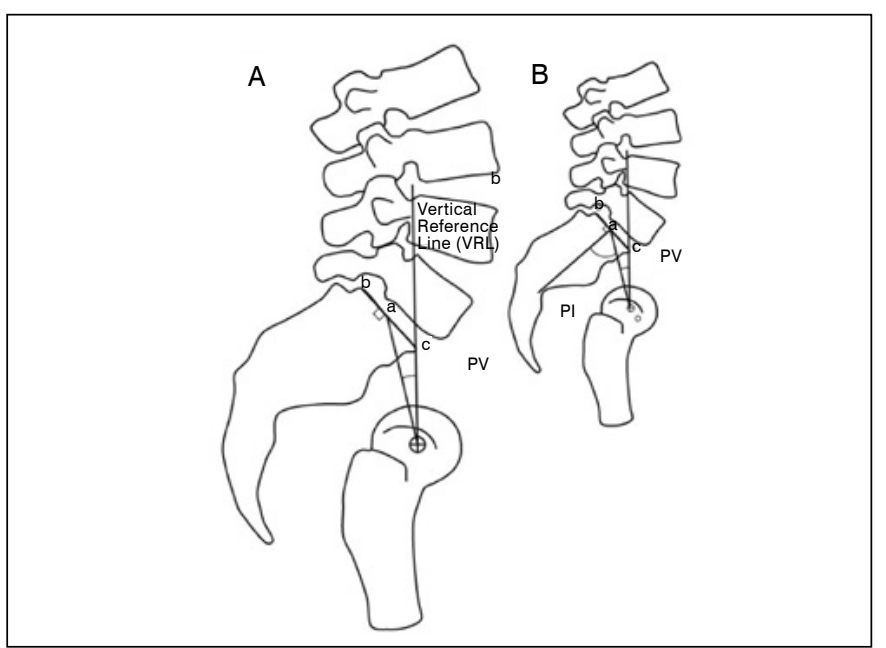

Figure 2. Pelvic version (PV) is the angle formed by crossing a vertical line that passes through the femoral head (o) and middle point of the sacral plateau (a). PV and PI share same (o-a) line and sacral plateau as reference $(B)$.

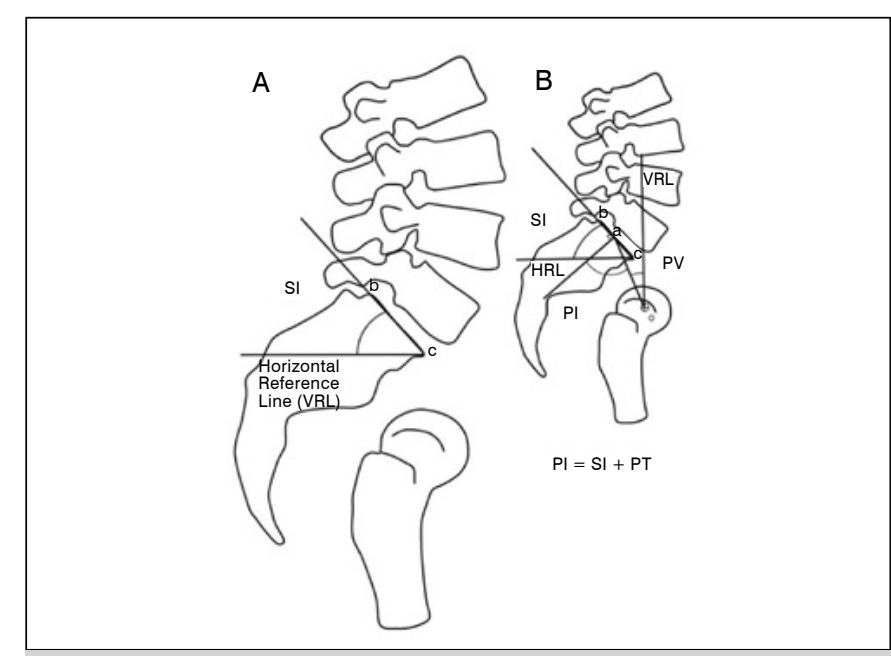

Figure 3. Sacral inclination (SI) is defined as the angle formed by crossing a horizontal reference line (HRL) and the anterior tip of the sacral plateau (b-c). SI, PI and PV share same (b-c) line throughout the sacral plateau (B). 


\section{Data collected and statistical analyses}

Statistical analyses from all data collected in this study was initially performed in a descriptive manner. Quantitative parameters (numerical) such as age, PI, SI, PV and time since turning professional soccer player, were calculated as summary measures: mean, minimum, maximum and standard-deviation. Qualitative parameters (categorical) were analyzed using absolute and relative (\%) frequencies. Agreement between readers for pelvic parameters measurements was performed by Bland-Altman graphs and intraclass correlation coefficient (ICC).ICC values interpretation followed levels proposed by Altman (1990), being classified as poor $(<0.2)$, fair (0.2-0.4), moderate (0.4-0.6); good (0.6-0.8) and excellent (>0.8). Student t-test for independent samples was used to assess correlation between pelvic measurements and radiographic signs of osteitis pubis, while Fisher's exact test was used to assess correlation between osteitis pubis and player's position in soccer field.

Statistical Package for the Social Sciences (SPSS) software version 16 was used to run all analyses, with significance level set to $5 \%$.

\section{RESULTS}

Our study group comprised a total of 107 professional soccer players, all male, with a mean age of $25.6 \pm 3.1$ years old. Three subjects were excluded due to the absence of pelvic radiographs from their childhood (Table 1).

Regarding reproducibility of pelvic measurements, we can see in Bland-Altman graphs the behavior of the differences between means from both readers (Figure 4). The line in red represents difference between means, and lines in green a 95\% confidence interval. Overall, in all three parameters, readers achieved very similar values (mean difference varying from $-0.6^{\circ}$ to $1.0^{\circ}$ ), demonstrating an excellent agreement (Table 2).

Although PI, SI and PV angles were higher in players with osteitis pubis, there was no statistical correlation between these parameters (Table 3). PV angles in left-footed kickers were significantly greater when compared to right-footed kickers (Table4). There was no correlation between the presence of osteitis pubis and player position in the field (Table 5).

Table 1. Demographic, clinical and Imaging characteristics.

\begin{tabular}{|c|c|}
\hline Parameters & Results \\
\hline Age (years), mean \pm standard-deviation (SD) & $25.6 \pm 3.1$ \\
\hline Time since becoming professional (years), mean \pm SD & $5.6 \pm 2.0$ \\
\hline \multicolumn{2}{|l|}{ Dominant leg, $n(\%)$} \\
\hline Right & $93(86.9)$ \\
\hline Left & $14(13.1)$ \\
\hline \multicolumn{2}{|l|}{ Field position, $\mathrm{n}(\%)$} \\
\hline Striker & $24(22.4)$ \\
\hline Goalkeeper & $7(6.5)$ \\
\hline Right forward & $9(8.4)$ \\
\hline Left forward & $4(3.7)$ \\
\hline Midfielder & $36(33.6)$ \\
\hline Forward & $3(2.8)$ \\
\hline Defender & $24(22.4)$ \\
\hline Pain symptoms (pelvis, spine or hips), $n(\%)$ & $2(1.9)$ \\
\hline \multicolumn{2}{|l|}{ Pelvic parameters $\left({ }^{\circ}\right)$, mean \pm SD } \\
\hline Pelvic incidence $(\mathrm{PI})$ & $51.1 \pm 11.9$ \\
\hline Sacral inclination (SI) & $41.8 \pm 9.3$ \\
\hline Pelvic version (PV) & $9.3 \pm 6.9$ \\
\hline \multicolumn{2}{|l|}{ Imaging findings, $\mathrm{n}(\%)$} \\
\hline Listhesis & $6(5.6)$ \\
\hline Spondylolysis & $6(5.6)$ \\
\hline Osteitis pubis & $80(74.8)$ \\
\hline
\end{tabular}

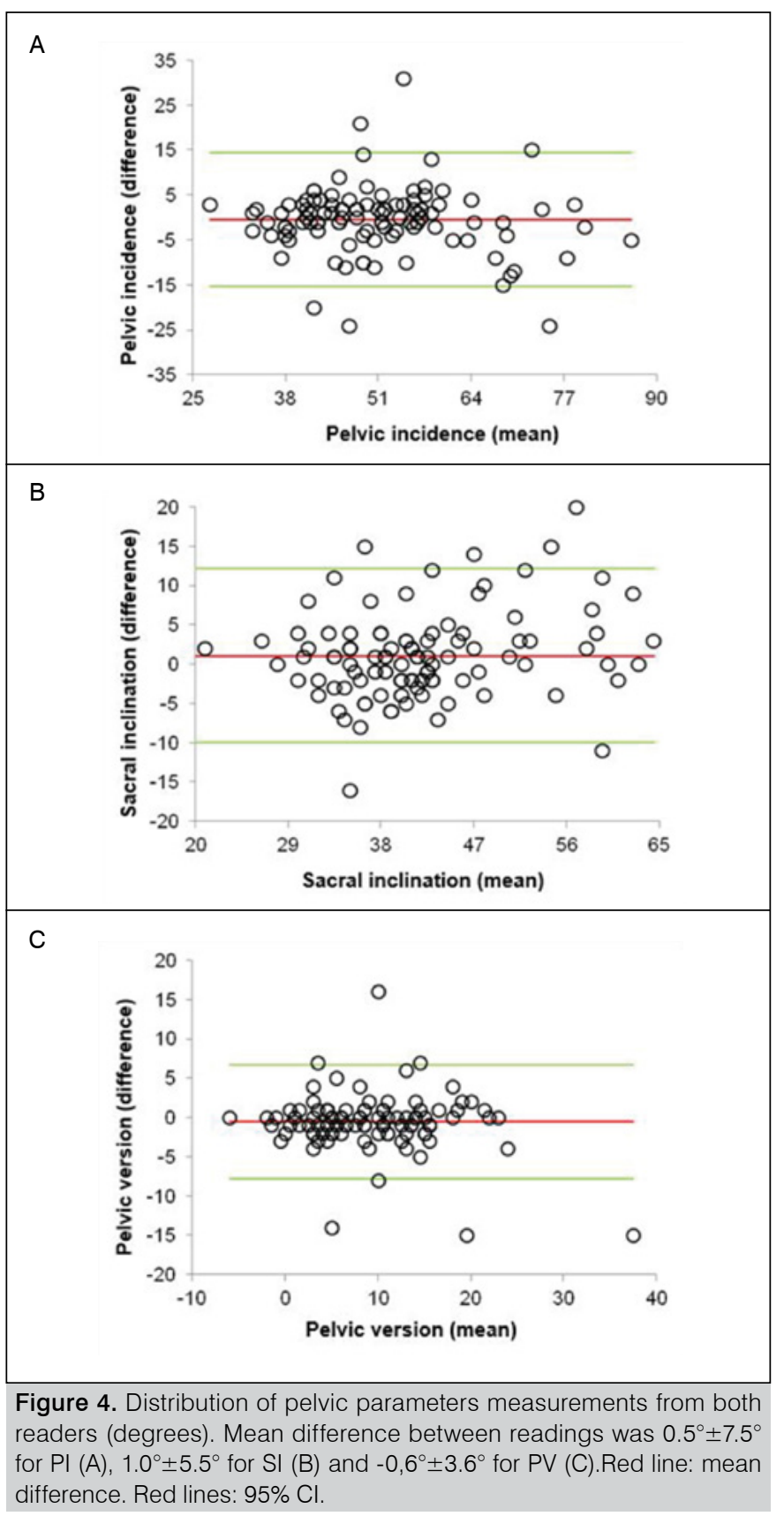

Table 2. Agreement bewteen readers.

\begin{tabular}{c|c|c|c}
\hline Pelvic parameters & $\begin{array}{c}\text { Intraclass Correlation } \\
\text { Coefficient, ICC [Cl 95\%] }\end{array}$ & Agreement & $\mathbf{p}$ \\
\hline Pelvic incidence & $0.892[0.841-0.926]$ & Excellent & $<0,0001$ \\
\hline Sacral inclination & $0.901[0.854-0.933]$ & Excellent & $<0,0001$ \\
\hline Pelvic version & $0.924[0.888-0.948]$ & Excellent & $<0,0001$ \\
\hline
\end{tabular}

\section{DISCUSSION}

Our results indicate that $\mathrm{PI}$ angles were greater in Professional soccer players presenting with osteitis pubis, especially in midfielders, although such correlation did not present statistical significance. We believe that these results might be different if bigger samples were tested. On the other hand, reproducibility of measurements from both readers was excellent for all three parameters, which was also reported by Lafage et al. ${ }^{13}$ 
Table 3. Correlation between pelvic parameters and osteitis pubis.

\begin{tabular}{c|c|c|c}
\hline Pelvic parameters & \multicolumn{3}{|c}{ Osteitis Pubis } \\
\hline & Present $(\mathbf{n}=80)$ & Absent $(\mathbf{n}=27)$ & t-test $(\mathbf{p})$ \\
\hline Pelvic incidence & $52.3^{\circ} \pm 12.7^{\circ}$ & $48.4^{\circ} \pm 10.8^{\circ}$ & 0.156 \\
\hline Sacral inclination & $43.1^{\circ} \pm 9.8^{\circ}$ & $39.9^{\circ} \pm 10.1^{\circ}$ & 0.146 \\
\hline Pelvic version & $9.2^{\circ} \pm 6.3^{\circ}$ & $8.6^{\circ} \pm 7.5^{\circ}$ & 0.649 \\
\hline
\end{tabular}

\begin{tabular}{c|c|c|c}
\multicolumn{3}{|c}{ Table 4. Correlation between pelvic parameters and dominant leg. } \\
\hline Pelvic parameters & \multicolumn{3}{|c}{ Dominant leg } \\
\hline & Right $(\mathbf{n}=93)$ & Left $(\mathbf{n}=14)$ & t-test $(\mathbf{p})$ \\
\hline Pelvic incidence & $50.7^{\circ} \pm 11.3^{\circ}$ & $56.0^{\circ} \pm 17.3^{\circ}$ & 0.281 \\
\hline Sacral inclination & $42.3^{\circ} \pm 9.1^{\circ}$ & $42.3^{\circ} \pm 14.7^{\circ}$ & 0.997 \\
\hline Pelvic version & $8.4^{\circ} \pm 5.9^{\circ}$ & $13.7^{\circ} \pm 8.6^{\circ}$ & 0.04 \\
\hline
\end{tabular}

Table 5. Correlation between osteitis pubis and player position in the field.

\begin{tabular}{c|c|c|c|c}
\hline Position & \multicolumn{3}{|c|}{ Osteitis pubis } & p \\
\hline & Yes (\%) & No & Total & \\
\hline Stricker & $18(75)$ & 6 & 24 & 1.000 \\
\hline Goalkeeper & $3(42)$ & 4 & 7 & 0.066 \\
\hline Right forward & $7(77)$ & 2 & 9 & 1.000 \\
\hline Left forward & $3(75)$ & 1 & 4 & 1.000 \\
\hline Midfielder & $30(83)$ & 6 & 36 & 0.166 \\
\hline Forward & $2(67)$ & 1 & 3 & 1.000 \\
\hline Defender & $17(70)$ & 7 & 24 & 0.603 \\
\hline Total & $80(74)$ & 27 & 107 & \\
\hline \multicolumn{4}{|c}{}
\end{tabular}

Soccer is a sport modality that involves high-intensity motor actions and sudden modifications, especially during fundamentals movements, promoting a particular biodynamic profile. In this setting, the current study aimed to identify the relationship between presence of osteitis pubis and pelvic parameters, especially PI, since such measure is specific and constant for each individual by the end of osseous growth and skeletal maturity, regardless of the radiographic view, either extension, flexion or neutral position of the hips. ${ }^{3,6,8,10,11}$

Although a relationship between $\mathrm{Pl}$ and osteitis pubis might be possible, as seen in the current study, there is no data on literature that corroborates isolated relation of cause-effect between them. Nonetheless, the results obtained suggest greater PI values in subjects presenting with osteitis pubis. In Figure 5 we can see an example of a subject with findings of osteitis pubis (sclerosis and superior symphysis margin fragmentation) but low PI angle $\left(38^{\circ}\right)$. On the other hand, subjects with increased $\mathrm{Pl}$ angles may not present degenerative changes in pubic symphysis, as exemplified in Figure $6\left(\mathrm{PI}=81^{\circ}\right)$. Since PI is defined by the sum of the two other components to maintain the sagittal balance (SI and PV), during the active period of the soccer player, his field position and specific biomechanics, this balance may change with compensatory adaptative changes in SI and PV. However, such changes, even though they preserve a constant PI value, they come along with ancillary forces restructuration that contributes to maintain the balance, such as myotendinous and aponeurotic forces. Anterior abdominal

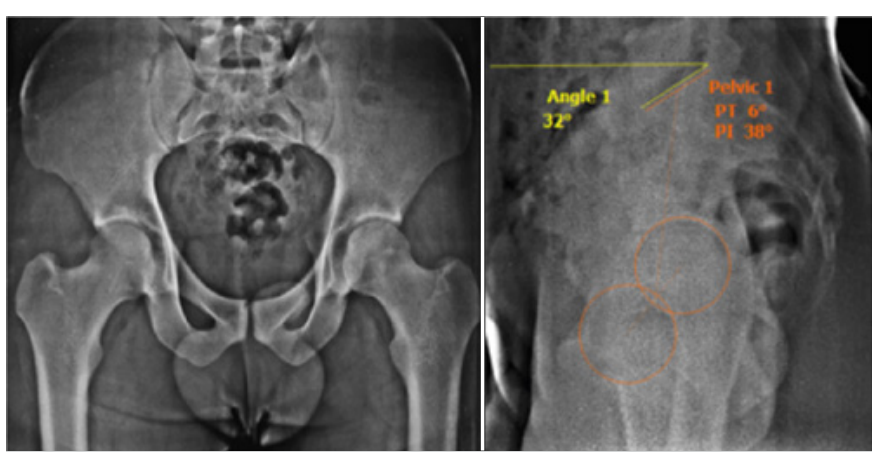

Figure 5. Radiographs of the pelvis showing osteitis pubis (AP view, left image) with $\mathrm{PI}$ of $38^{\circ}$ (lateral view, right image).

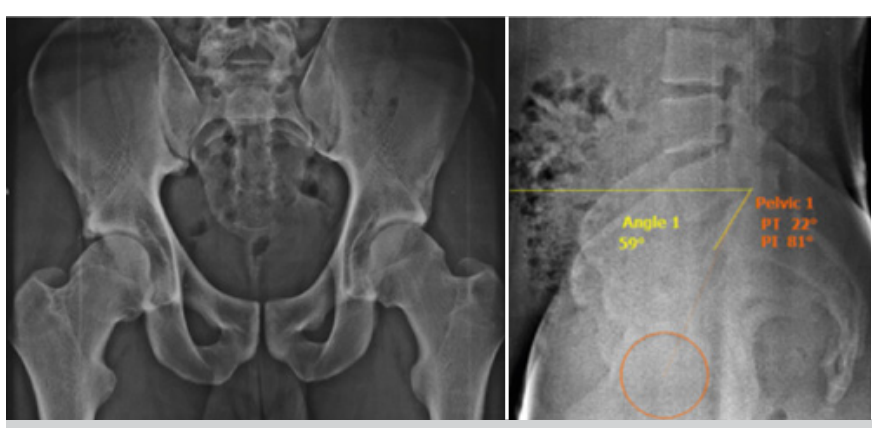

Figure 6. Radiographs of the pelvis showing normal symphysis pubis (AP view, left image) with PI of $81^{\circ}$ (lateral view, right image).

hyperextension and hip hyperabduction, frequent movements in professional soccer activity (sudden acceleration, lateral movement and fast changes in direction and kicking) generate chronic overuse over the pubic symphysis. 6,8,9,14

Considering that $\mathrm{Pl}$ is a strong determinant of the special orientation of the pelvis in orthostatic position, we question if abnormalities in these values can determine a specific dynamic in myotendinous and aponeurotic structures forces during movement. Since we believe that osteitis pubis is multifactorial, we included other possible risk factors in our analyses, such as: time since becoming professional player, field position and dominant leg. The union of these factors may lead to higher or lower degree of overload to the pubic symphysis. . $, 5,8,15$

Radiographic evaluation of these subjects must include lateral views of the femoral heads to measure pelvic parameters and, thus, the sagittal balance. Along with ancillary components to maintain the balance, they can aid to customize each athlete training plan to avoid future lesions. ${ }^{5,6,8,15}$

Our study has been limited to simple radiographs of the pubic symphysis, a method in which findings are not always positive in relation to the symptoms (pubalgia), opposite to magnetic resonance that allows evaluate edema in acute phase, as well as myotendinous and aponeurotic structures of rectus abdominis and adductors, bringing increased correlation of imaging findings to clinical symptoms of the athlete during the evaluation., ${ }^{1,3,9}$

In conclusion, our data shows that evaluation of pelvic parameters is highly reproducible, presenting excellent inter-observer agreement. There was no correlation between pelvic incidence angles measurements and the presence of osteitis pubis in professional soccer players.

AUTHORS' CONTRIBUTION: Each author made significant individual contributions to this manuscript.. Rodrigues FM: conceptualization, execution, and writing, Taneja AK: writing and critical review, Narahashi E and Silva FD: reading of the cases and data tabulation, Fernandes ARC: critical review and supervision, Falotico GG: clinical evaluation of the patients and orthopedic consultation, Yamada AF: conceptualization, supervision, and guidance. 


\section{REFERENCES}

1. Fricker PA, Taunton JE, Ammann W. Osteitis pubis in athletes. Infection, inflammation or injury? Sports Med. 1991;12:266-79.

2. Andrews SK, Carek PJ. Osteitis pubis: a diagnosis for the familyphysician. J Am BoardFamPract.1998;11:291-95.

3. Cunningham PM, Brennan D, O'Connell M, MacMahon P, O'Neill P, Eustace S, Patterns of bone and soft-tissue injury at the symphysispubis in soccer players: observationsat MRI. AJR Am J Roentgenol. 2007; 188: W291-296.

4. Ruane JJ, Rossi TA. Whengroinpainis more than 'just a strain': navigating a broaddifferential. PhysSportsmed.1998;26:78-103.

5. Zoga AC, Kavanagh EC, Omar IM, et al. Athletic pubalgia and the 'sportshernia': MR imagingfindings. Radiology. 2008; 247:797-807.

6. Fricker PA. Osteitis pubis. Sports medicine and arthroscopyreview. 1997; 305-12.

7. Batt ME, McShane JM, Dillingham MF. Osteitis pubis in collegiatefootball players Med Sci Sports Exerc.1995;27:629-33.

8. Tebet MA. Currentconceptson the sagittal balance and classification of spondylolysis and spondylolisthesis. RevBras Ortop. 2014;49:3-12.
9. Coventry MB, Mitchell WC. Osteitis pubis: observationsbasedon a study of 45 patients. JAMA.1961;178:898-905

10. SF Fanton. Osteitis pubisetiology and treatment. In Sports Medicine 1997: An NFL perpective. San Francisco, CA; 1997.

11. Vitanzo PC, McShane JM. Osteitis pubis: solving a perplexing problem. PhysSportsmed. 2001;29:33-48.

12. Berthonnaud E, Labelle H, Roussouly P, Grimard G, Vaz G, Dimnet J. A variability study of computerized sagittal spinopelvic radiologic measurements of trunk balance. J Spinal Disord Tech. 2005;18(1):66-71.

13. Lafage R, Ferrero E, Henry JK, et al. Validation of a new computer-assisted tool to measurespino-pelvicparameters. Spine J. 2015;15: 2493-502.

14. Henry T Goitz. Osteitis Pubis. Medscape. [Internet]. Jun 2018 [accessed on 2019 nov 10]. Available at: https://emedicine.medscape.com/ article/87420-overview.

15. Koulouris $\mathrm{G}$. Imaging review of groin pain in elite athletes: ananatomic approach to imaging findings. AJR Am J Roentgenol. 2008; 191: 962-72. 